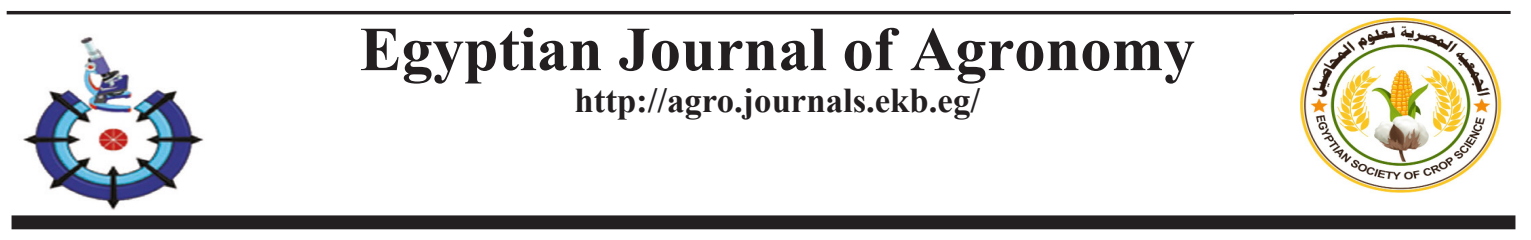

\title{
Study of the Effect of Different Types of Previous Crops on the Dynamics of the Weed Flora under No-Till Condition in Algeria
}

\author{
Bilal Fortas $^{(1,3) \#, \text { Amar Rouabhi }}{ }^{(2,3)}$, Abdelhamid Mekhlouf $\mathbf{f}^{(2,3)}$ \\ ${ }^{(1)}$ Department of Natural Sciences, Higher School of Technological Education of \\ Skikda, Algeria; (2)Department of Agricultural Sciences University Ferhat Abbas, \\ Setif 1, Algeria; (3)Laboratory for Improvement and Development of Plant and \\ Animal Production (LIDPAP), Algeria.
}

\begin{abstract}
7 HIS STUDY aims to evaluate the impact of crop rotations on weed dynamics under no-till conditions. Four crop rotations were tested:Wheat/Lentil/Wheat (W/L/W), Lentil/Wheat/Wheat (L/W/W), Triticale/forage Pea/Wheat (T/P/W) and forage Pea/Triticale/ Wheat (P/T/W), during the 2016/17, 2017/18 and 2018/19 crop years. The experiment was conducted on the experimental site belonging to the ITGC-FEA of Setif (Algeria). The results indicate that the weed flora is composed of 13 species belonging to 09 families. Dicotyledons are mostly observed during the three campaigns, with proportions of $77.77 \%, 66.66 \%$, $84.62 \%$, respectively for the campaigns 2016/17, 2017/18 and 2018/19. Annual grasses (monocotyledons) consisted of Avena sterilis and Bromus sterilis. The Shannon and Simpson indices show controversial values depending on the treatments applied. The W/L/W crop rotation was distinguished by both specific diversity and low dominance, conversely the P/T/W treatment, shows high dominance accompanied by low diversity. The linear model relating to the evolution of monocots as a function of precipitation shows that they are negatively and significantly correlated with precipitation in January. The latter is as follows: $\mathrm{Y}=-0.251 \mathrm{x}+$ 34.461 with $\left(\mathrm{R}^{2}=0.998\right)$.
\end{abstract}

Keywords: Crop rotation, No-till, Semi-arid, Shannon Entropy, Weed flora.

\section{Introduction}

No-till was introduced in Algeria and in particular in the semi-arid zone of the high plains of Sétif during 2006, following the comforting results obtained elsewhere in Mediterranean countries (Zaghouane et al., 2006). This system was adopted and popularized by a group of farmers organized as an association called "Traitd'union", which has set itself the mission of developing conservation agriculture through direct seeding. The adoption of this system generates a strong proliferation of weeds, following the abandonment of tillage (Dorado \& Lopez-Fando, 2006; Rahali et al., 2010; Ruisi et al., 2015). In the no-till system, weed management is an essential constraint in addition to the availability of an adapted seeder and other economic constraints in Algeria (Rouabhi et al.,
2018). The adoption of this system induces both biological modifications of the soil and a new composition of weed communities. Thus, only the chemical option paired with the practice of rotation and the use of competitive varieties is possible.

Therefore, the study of the evolution of the weed flora under the effect of the rotations is of major interest. the weed flora management is an important aspect of culture systems since these foreign plants to culture can easily cause yield losses of up to $70 \%$ (Tanji, 2005). In the conventional system, many alternatives are available, including ploughing, shallow tillage, and false seeding (Rasmussen, 2004), which aim to reduce the seed bank by promoting the emergence of weeds (Hamadache, 1995; Gallandt, 2006). However, these techniques can

"Corresponding author email: billel_pm@yahoo.fr, b.fortas@enset-skikda.dz

Received 14/08/2021; Accepted 13/12/2021

DOI : 10.21608/agro.2021.90486.1274

C2021 National Information and Documentation Center (NIDOC) 
have negative impacts on soil quality (lowering of fertility) and soil erosion (Dickey et al., 1983; Gallandt, 2004). In no-till, these tools offered are no longer available in the management of the weed flora and the system is confronted with the constraint of weed proliferation (Dorado et al., 1999; Fortas et al., 2013). In this regard, the optimization and mobilization of other levers are more than essential. Among, the alternatives offered, the use of the herbicide Glyphosate with a broad spectrum of action, possessing a major asset for the control of weeds before seeding.

It is in this context that our contribution aims, namely the study of the effect of the crop rotation on the temporal dynamics of the weed flora under no-till conditions management.

\section{Materials and Methods}

The study was carried out during the $2016 / 17,2017 / 18$ and $2018 / 19$ crop years at the experimental site of the Technical Institute of Field Crops (ITGC) of Setif, whose geographical coordinates are: $36^{\circ} 15^{\prime} \mathrm{N}$ and $05^{\circ} 37^{\prime} \mathrm{E}$ with an altitude of 975 m.a.s.l. The climate of the region is Mediterranean, continental, semi-arid, characterized by a hot and dry summer and a cold and wet winter (Chennafi et al., 2006). The soil physical and chemical analyses were carried out at the farm lab during the 2016/17 campaign. The results show that the soil texture is of loam type according to USDA textural triangle, the soil is shallow with poor drainage (presence of calcareous hardpan at $20 \mathrm{~cm}$ depth), and a highwater retention capacity. This soil type represents a risk of potassium retrogradation and a risk of phosphorus blockage due to $\mathrm{pH}$ (Alkaline), as well as root asphyxiation in extreme cases (Girard et al., 2011). The low carbon/nitrogen ratio indicates a rapid mineralization of the organic matter (Gobat et al., 2013). Some physical and chemical

TABLE 1. General soil properties at the ITGC station, conducted under No-till system in 2017

\begin{tabular}{lc}
\hline Properties & Values \\
\hline Clays & $16 \%$ \\
Silt & $48 \%$ \\
Sand & $36 \%$ \\
Texture & Loam \\
$\mathrm{pH}$ & 8.85 \\
Organic matter & $1,68 \%$ \\
\hline
\end{tabular}

properties of this soil are shown in Table 1.

The amounts of precipitation recorded during the three-crop campaigning (2016-17, 2017/2018 and 2018/19) from September to June are 187.9 mm, $442.10 \mathrm{~mm}, 346.6 \mathrm{~mm}$, respectively (Fig. 1). Data reveal a large temporal variation for the three seasons. In the semi-arid zone, cereal cultivation is subject to a strong variation in precipitation, which induces a great fluctuation in yields and production. The 2016/17 season is the least favourable compared to the other two seasons; the difference compared to the next two seasons appears during the spring period, March-April, and May, with amounts of $0 \mathrm{~mm}$, $5.2 \mathrm{~mm}, 9 \mathrm{~mm}$, respectively, which led to a deficit of $184.7 \mathrm{~mm}$, or $49.57 \%$ compared to the average rate received for the other two campaigns (Fig. 1). However, the $2017 / 18$ crop year is relatively favourable, marked by a high monthly cumulative precipitation of $90.40 \mathrm{~mm}$ in March and the lowest in October $10.70 \mathrm{~mm}$. The $2017 / 18$ and 2018/19 crop years are characterized by a spring and a rainy end of cycle (months of April, May, and June) with a respective cumulative rate of $172.30 \mathrm{~mm}, 102.40 \mathrm{~mm}$. This favourable period coincides with the meiosis-epiaison and grain filling phases. From the point of view of temperature analysis, whose distribution is high in summer and relatively low in winter, which limits the growth of the plant and does not allow the plant to valorise the winter precipitation. In this regard, Haddad (2017) suggests that selection should target genotypes that tolerate low temperatures during the vegetative phase and high temperatures during the reproductive phase.

\section{The experimental protocol and plant material}

The experiments are carried out according to a randomly completely block design with a single factor as previous crops $(\mathrm{W} / \mathrm{L} / \mathrm{W}, \mathrm{T} / \mathrm{P} / \mathrm{W}$, $\mathrm{L} / \mathrm{W} / \mathrm{W}, \mathrm{P} / \mathrm{T} / \mathrm{W}$ ) including four crops (Durum wheat $(\mathrm{W})$, triticale $(\mathrm{T})$, lentil $(\mathrm{L})$, and forage pea (P)); the aftereffects of which we wanted to assess on the evolution of the weed flora. The block is composed by four elementary plots, each treatment is repeated three times. The experiment therefore comprises twelve plots, each one with $50 \mathrm{~m}$ long and $09 \mathrm{~m}$ wide. Plant material included: i) Bousselem (pedigree: Can2109// jo / aa / 3/ $\mathrm{s} 15$ / cr) as durum wheat variety (Triticum durum, Desf), ii) triticale (Triticosecale Wittm), iii) Dahra lentil variety (Lens culinaris L.) and iv) Seffrou forage pea variety (Pisum sativum $\mathrm{L}$ ). The sowing

Egypt. J. Agron. 43, №. 3 (2021) 
dates are carried out during the $3^{\text {rd }}$ ten days of December of each year at doses: durum wheat at 300 seeds $/ \mathrm{m}^{2}$, triticale 250 seeds $/ \mathrm{m}^{2}$ and 200 seeds for lentil and forage peas. Previously, the seeds were treated with a fungicide Celest Extra $25 \mathrm{~g} / \mathrm{L}$ fludioxonil $+25 \mathrm{~g} / \mathrm{L}$ difenoconazole. The sowing operation was done with a commercial direct seeder (John Shearer) at a depth of $3 \mathrm{~cm}$. This drill allows for $23 \mathrm{~cm}$ spacing between the seed rows. The plot was treated just before seeding with glyphosate [N-phosphonomethyl-glycine, $\left.\mathrm{C}_{3} \mathrm{H}_{8} \mathrm{NO}_{5} \mathrm{P}\right]$ at a rate of $360 \mathrm{~g} / \mathrm{L}$ of the commercial product at a rate of $3 \mathrm{l} / \mathrm{ha}$ in 250 liters of water per hectare. The control of weeds on cereals (durum wheat, triticale) is carried out chemically against dicotyledons with Zoom, dispersible granulated formulation $(65.9 \%$ Dicamba $+4.1 \%$ Triasulfuron) at a rate of $150 \mathrm{~g} / \mathrm{ha}$, and Topik $80 \mathrm{EC}$ (80g/L of Clodinafop-propargyl), against grasses at a rate of $0.75 \mathrm{~L} /$ ha The trial was fertilized with the MAP bottom dressing at 52\% phosphorus, at a rate of $50 \mathrm{~kg} / \mathrm{ha}$ combined with the sowing (localized fertilization). Nitrogen fertilization was applied during the tillering phase at a rate of $46 \mathrm{U} / \mathrm{ha}$ of urea at $46 \%$.

\section{Method of study of the weed flora Species determination}

The monitoring of the dynamics of the weed flora is carried out over a period of 03 agricultural campaigns (2016/2017, 2017/2018 and 2018/2019), through four surveys during the cycles of the culture: a 1st sampling is carried out before sowing and weeding with glyphosate, followed by a $2^{\text {nd }}$ after the total chemical treatment and a $3^{\text {rd }}$ counting is carried out before catch-up weeding followed by a 4th after the last chemical treatment. A Quadra of $01 \mathrm{~m}^{2}$, chosen at random, is used for the follow-up and the counting of the various weed species. For the determination and identification of the species we used the " Guide to cereal weeds in Algeria " (ITGC; 1976) and the book: "Wheat and barley weeds in Morocco" (Tanji; 2005).

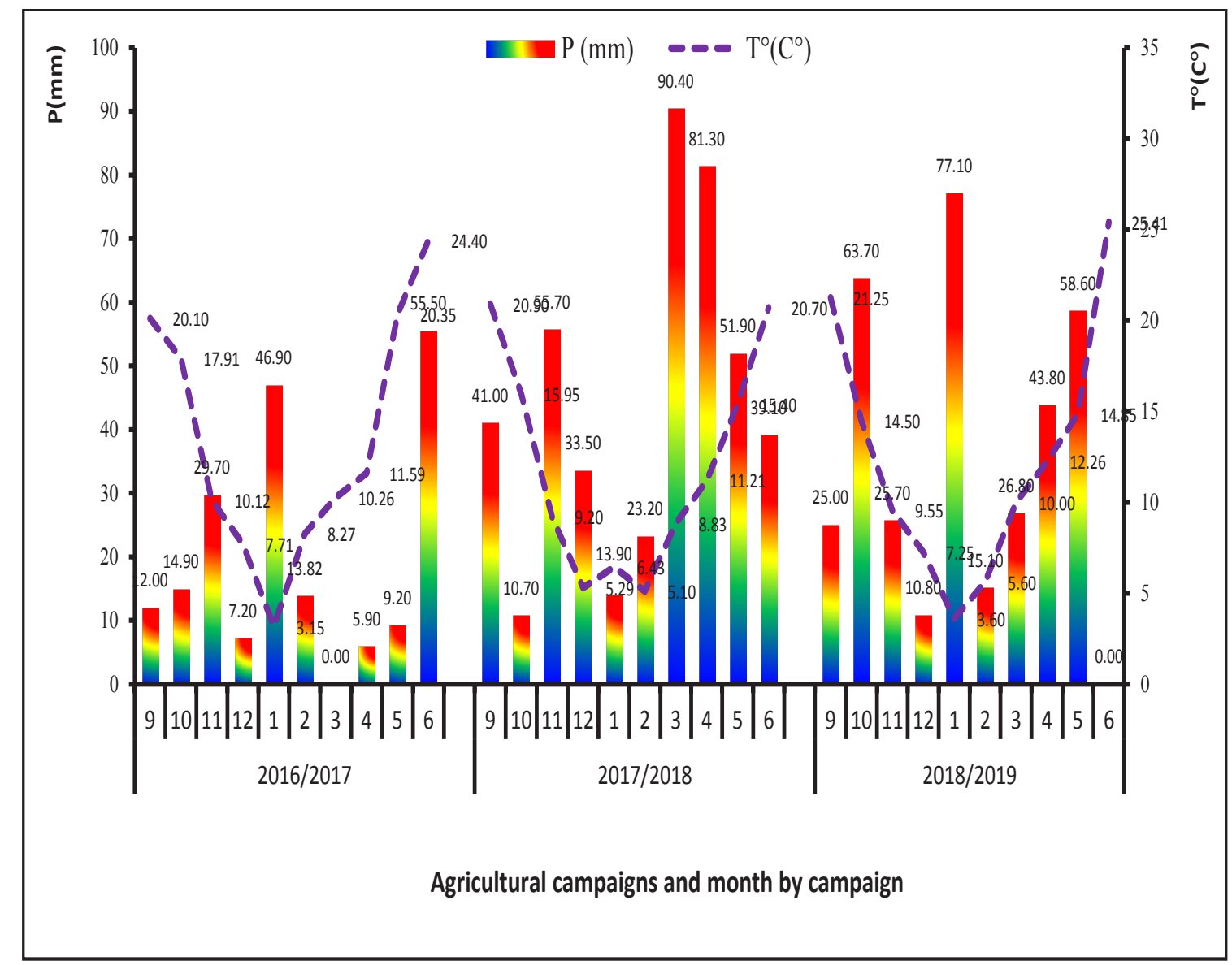

Fig. 1. Monthly average precipitation and temperature of the 2016/17, 2017/18 and 2018/19 campaigns at the IITGC experimental site (ONM, 2019) 
Study of the flora diversity

The study of the diversity of the weed populations on the 03 campaigns of studies and for the various cultural rotations calls upon the calculation of the index of diversity of SHANON-WIENER and the equitability.

A/ SHANON-WIENER diversity index: The SHANON-WIENER diversity index $\left(\mathrm{H}^{\prime}\right)$ is the quantity of information provided by a sample on the structures of the stand from which the sample comes and on the way in which the individuals are distributed between various species (Dajet, 1976). According to Dajoz (1975), diversity is the function of the probability Pi of presence of each species $i$ in relation to the total number of individuals:

$H^{\prime}=-\sum(n i / N) \cdot \log 2(n i / N)$

H': specific diversity. $\mathbf{N}$ : sum of the number of species, ni: number of the population of the species $\mathbf{i}$.

B/ Equitability (equipartition): The equitability constitutes a second fundamental dimension of diversity (Ramade, 1994). According to Dajoz (1996), it is expressed as follows:

\section{$\mathrm{E}=\mathrm{H}^{\prime} / \mathrm{Hmax}$ of which $\mathrm{Hmax}=\log 2(\mathrm{~s})$}

S: Is the number of species forming the population. Equitability allows comparison of population structures.

C/ Simpson's dominance index: This measure is also known in ecology as the probability of interspecific encounter (PIE) (Hurlbert, 1971) and the GiniSimpson index (Jost, 2006). It can be expressed as a transformation of the true diversity of order 2 :

$\lambda=1-\frac{\sum \mathbf{n i}(\mathbf{n i}-\mathbf{1})}{\mathrm{N}(\mathrm{N}-1)}$

\section{Statistical analysis}

The data processing was done with the software Past paleontological statistics software packaged for education and data analysis, Current version (May 2021): 4.06 b.

Another multidimensional descriptive analysis was performed; it is the Principal Component Analysis (PCA), whose purpose is to present and study the different variables selected for a system of components, this analysis is performed using Xlstat premium 2018.1 software.

Egypt. J. Agron. 43, No. 3 (2021)

\section{Results and Discussions}

Structure of the flora according to the agricultural season and crop rotations

The qualitative floristic analysis allows to define the composition of the weed flora of the crops, while the quantitative floristic analysis allows to describe the agronomic importance of the species according to their relative frequency and abundance. The weed flora was diversified, of which 13 species belonging to 7 families were recorded across the 04 crop rotation types $(\mathrm{W} / \mathrm{L} / \mathrm{W} ; \mathrm{L} / \mathrm{W} / \mathrm{W} ; \mathrm{T} / \mathrm{P} / \mathrm{W}$ and $\mathrm{P} / \mathrm{T} / \mathrm{W}$ ) and during the 03 study (Table 2). During the first campaign (2016/2017), the weeds recorded were divided into 03 groups. The dicotyledons with $77.77 \%$ of the weed population, are composed of annuals and perennials. The therophytes are formed of 04 families, counting five annual species, namely: Sonchus asper, Polygonum aviculare, Papaver rhoeas, Raphanus raphanistrum and Sinapis arvensis. The annual grasses identified are Avena sterilis and Bromus sterilis and account for about $22.22 \%$ (Table 2). The cryptophytes (perennials) are present with two families, namely the Brassicaceae and the Asteraceae, with respectively Diplotaxis assurgens and Cirsium arvensis. The second campaign has seen a reduction compared to the previous campaign; annual and perennial dicotyledons account for $66.66 \%$ and are represented by two families; Asteraceae and Brassicaceae and four species, namely Sonchus asper, Raphanus raphanistrum for annuals and Cirsium arvensis and Diplotaxis assurgens for perennials (Table 3), while the annual grasses formed by Avena sterilis and Bromus sterilis with $33.33 \%$ of the total population of weeds However, in the third campaign, all plots were sown with durum wheat, and the surveys carried out allowed to highlight the effect of the different treatments on the dynamics of the weed flora. On this subject, we note a qualitative and quantitative proliferation of the weed flora. The surveys indicate the presence of nine different families and thirteen species, $84.62 \%$ and $15.38 \%$, respectively, for the dicotyledons and monocotyledons (Table 2). The recrudescence is located at the level of dicotyledons through the appearance of new annual species such as Gallium aparine and Fumaria parviflora Lam belonging to Rubiaceae and fumariaceae respectively. We also note the appearance of the biennial plant wild carrot of the Apiaceae family. However, the annual grasses are still represented by Bromus sterilis and Avena sterilis. 
TABLE 2. The contribution of mono and dicotyledons in the weeds listed

\begin{tabular}{|c|c|c|c|c|c|c|c|c|c|c|}
\hline \multirow{2}{*}{$\begin{array}{l}\text { Agricultural } \\
\text { campaigns } \\
\text { Classes } \\
\end{array}$} & \multicolumn{3}{|c|}{$2016 / 2017$} & \multicolumn{3}{|c|}{$2017 / 2018$} & \multicolumn{4}{|c|}{ 2018/2019 } \\
\hline & \multicolumn{2}{|c|}{ Dicots } & \multirow{2}{*}{$\begin{array}{l}\text { Monocots } \\
\text { 焉 }\end{array}$} & \multicolumn{2}{|r|}{ Dicots } & \multirow{2}{*}{$\begin{array}{l}\text { Monocots } \\
\text { 丞 } \\
\text { 离 }\end{array}$} & \multicolumn{3}{|c|}{ Dicots } & \multirow{2}{*}{$\begin{array}{c}\text { Monocots } \\
\text { 忢 } \\
\text { 宗 }\end{array}$} \\
\hline Biological types & 䄈 & 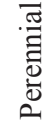 & & 焉 & 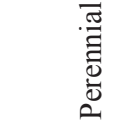 & & $\begin{array}{l}\overline{\text { G }} \\
\text { 妾 }\end{array}$ & 䄈 & 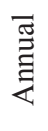 & \\
\hline N.Genus N. Species & 5 & 2 & 2 & 2 & 2 & 2 & 8 & 2 & 1 & 2 \\
\hline Contribution \% & & & 22,22 & & 66,66 & 33,33 & & 84,62 & & 15,38 \\
\hline
\end{tabular}

TABLE 3. The observed weed species and their biological type during the three campaigns

\begin{tabular}{|c|c|c|c|c|c|c|}
\hline $\begin{array}{l}\text { Agricultural } \\
\text { campaignS }\end{array}$ & Classes & $\begin{array}{c}\text { Biological } \\
\text { types }\end{array}$ & Family & Common name & Scientific name & $\begin{array}{l}\text { EPPO } \\
\text { code }\end{array}$ \\
\hline \multirow{9}{*}{ 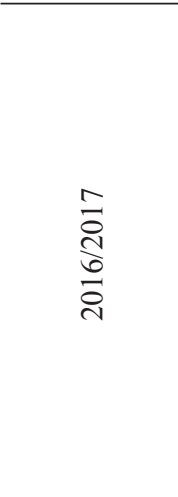 } & \multirow{7}{*}{ 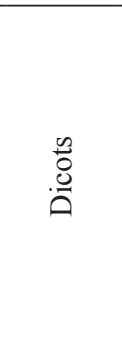 } & \multirow{5}{*}{ Annual } & Asteraceae & Field milk thistle & Sonchus asper & SONAS \\
\hline & & & Polygonaceae & Knotweed & Polygonum aviculare & POLAV \\
\hline & & & Papaveraceae & Poppy & Papaver rhoeas & PAPRH \\
\hline & & & Brassicaceae & Ravenelle & Raphanus raphanistrum & RAPRA \\
\hline & & & Brassicaceae & Field mustard & Sinapis arvensi $\mathbf{S}$ & SINAR \\
\hline & & \multirow{2}{*}{ Perennial } & Brassicaceae & Diplotaxis & Diplotaxis assurgens & DIPTE \\
\hline & & & Asteraceae & Thistle & Cirsium arvensis & CIRAR \\
\hline & \multirow{2}{*}{$\begin{array}{l}n \\
0 \\
0 \\
0 \\
0 \\
\vdots \\
\Sigma\end{array}$} & \multirow[b]{2}{*}{ Annual } & Poaceae & Brome & Bromus sterilis & BROST \\
\hline & & & Poaceae & Wild oats & Avena sterilis & AVELU \\
\hline \multirow{6}{*}{ 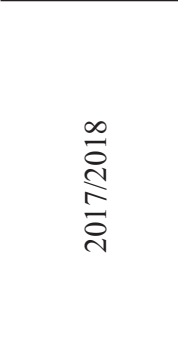 } & \multirow{4}{*}{ 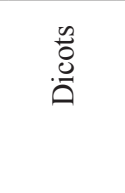 } & \multirow{2}{*}{ Annual } & Asteraceae & Field milk thistle & Sonchus asper & SONAS \\
\hline & & & Brassicaceae & Ravenelle & Raphanus raphanistrum & RAPRA \\
\hline & & \multirow{2}{*}{ Perennial } & Asteraceae & Thistle & Cirsium arvensis & CIRAR \\
\hline & & & Brassicaceae & Diplotaxis & Diplotaxis assurgens & DIPTE \\
\hline & \multirow{2}{*}{$\begin{array}{l}n \\
0 \\
0 \\
0 \\
0 \\
\Sigma\end{array}$} & \multirow[b]{2}{*}{ Annual } & Poaceae & Brome & Bromus sterilis & BROST \\
\hline & & & Poaceae & Wild oats & Avena sterilis & AVEFA \\
\hline \multirow{13}{*}{ 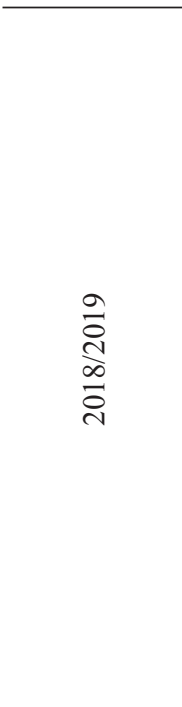 } & \multirow{11}{*}{$\begin{array}{l}0 \\
0 \\
0 \\
0\end{array}$} & \multirow{8}{*}{ Annual } & Asteraceae & Field milk thistle & Sonchus asper & SONAS \\
\hline & & & Brassicaceae & Ravenelle & Raphanus raphanistrum & RAPRA \\
\hline & & & Rubiaceae & Cleavers & Gallium aparine & GALA \\
\hline & & & Scrophulariaceae & Veronica & Veronica hederifolia & VERHE \\
\hline & & & Fumariaceae & Fumitory & Fumaria parviflora Lam & FUMPA \\
\hline & & & Polygonaceae & Knotweed & Polygonum aviculare & POLAV \\
\hline & & & Papaveraceae & Poppy & Papaver rhoeas & PAPRH \\
\hline & & & Brassicaceae & Field mustard & Sinapis arvensis & SINAR \\
\hline & & \multirow{2}{*}{ Perennial } & Asteraceae & Thistle & Cirsium arvensis & CIRAR \\
\hline & & & Brassicaceae & Diplotaxis & Diplotaxis assurgens & DIPTE \\
\hline & & $\begin{array}{l}\text { Biennial or } \\
\text { Perennial }\end{array}$ & Apiaceae & Wild carrot & Daucus carota & DAUCA \\
\hline & \multirow{2}{*}{$\begin{array}{l}n \\
0 \\
0 \\
0 \\
0 \\
\sum\end{array}$} & \multirow[b]{2}{*}{ Annual } & Poaceae & Brome & Bromus sterilis & BROST \\
\hline & & & Poaceae & Wild oats & Avena sterilis & AVEFA \\
\hline
\end{tabular}


Overall and in all treatments, there is a marked presence of dicotyledonous species compared to monocotyledons. This presence is greater in the legume rotations (forage pea and lens), compared to the previous cereals (durum wheat, triticale). This result seems to be linked to the combined effect of the early emergence of the grasses and the effect of the weed killer glyphosate (presowing operation).

In terms of quantity, among the species encountered, we recorded the presence of Avena sterilis, Bromus sterilis and Polygonum aviculare, whose abundance is remarkable. However, other species such as Sonchus arvensis L., Sinapis arvensis and Veronica hederifolia, are present at lower densities but their ability to form dense populations make them critical for crops (Benniou et al., 2016) (Table 3). The competition between weed species and the crop is established at the beginning of the vegetative crop cycle; from the 2-3 leaf stage (Montegut, 1980). This competition effect is more important during the early stages of the crop, it seems to be attributed to the fact that weeds absorb water and nutrients more easily than the crop (Le Bourgois, 1993). This competition becomes very competitive during tillering, and even more when weed seeds germinate deeper (Caussanel, 1989).

Correlation between the dynamics of weeds and the precipitation recorded in January during the 03 campaigns

The emergence of weeds in crop fields is spread over practically the whole year. The seeds present in the soil profile are in a physiological state favourable to their germination. The nondormant seeds are able to germinate as soon as the conditions become favourable (humidity, temperature, oxygen...). However, seeds are not always able to germinate and go through inhibition states (Jauzein, 1986; Popay et al., 1995). Seeds that fail to germinate under favourable conditions are considered dormant (Come \& Thevenot, 1982). Dormancy is a characteristic governed by the nature of the morpho-physiological state of the seed (Khan, 1980-1981) and the environmental conditions to which it is subjected. Thus, dormancy would be an adaptive state that optimizes the distribution of germination through time. This is the case of many seeds belonging to annual plants (therophytes, dicotyledons), which require important cold requirements (low temperatures) for the dormancy to be lifted.
The humidity (through precipitation) is an important factor that participates in the germination-raising of seeds and at the same time the propagation of weed plants in crop fields. In this regard, our research was interested in studying the effect of precipitation recorded in January on the spread of weeds afterwards. Indeed, January rainfall often coincided with the second wave of the dicotyledons emergence. Under semiarid environmental conditions, the temporal distribution of precipitation plays a major role in the germination of weed seeds, especially those in a dormant state. Figure 2 shows that there is a significant correlation between the volume of precipitation recorded in January over the three seasons covered by the study (Fig. 1) and the spread of weed plants.

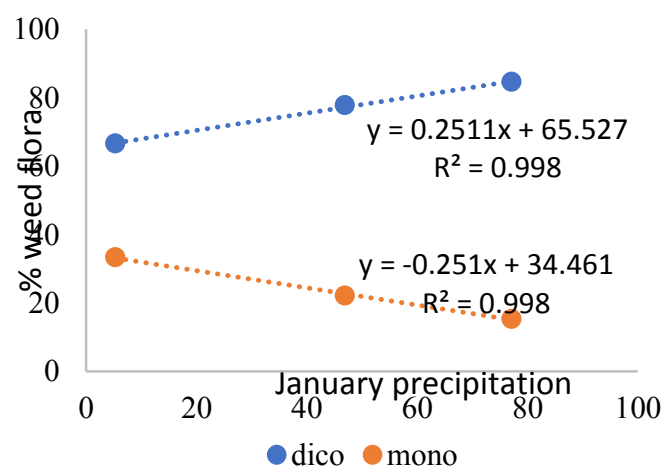

Fig. 2. Relation ship between January precipitation and the evolution of weed flora during the 03 campaigns.

The linear model concerning the evolution of the species number of dicotyledons weeds by plot as a function of precipitation recorded in January is $\mathrm{Y}=0.2511 \mathrm{X}+65.527$

This model significantly predicts the presence of weeds $\left(R^{2}=0,998\right)$, it indicates that the weed population increases with the increase of precipitation of this month (Fig. 2). However, the linear model related to the evolution of monocotyledons according to the precipitation of the same month shows that they are negatively and significantly correlated with the precipitation of the month of January (Fig. 3). The latter is as follows: $\mathrm{Y}=-0.251 \mathrm{X}+461$ with $\left(\mathrm{R}^{2}=0.998\right)$. The evolution of the weed flora in time is variable according to the campaigns and obeys relatively to the precipitations recorded during the month of January (Figus. 2 and 3). On this purpose, we note that the dicotyledonous species respond favourably to precipitation, this response seems to 
be attributed to the nature of these species, which are demanding in terms of low temperatures (conditionality of dormancy lifting), and whose germination-emergence occurs during this period (Fig. 3). Emberger (1971) pointed out that each type of climate affects the distribution of species and their development during the growing season through the precipitation and temperature regime.

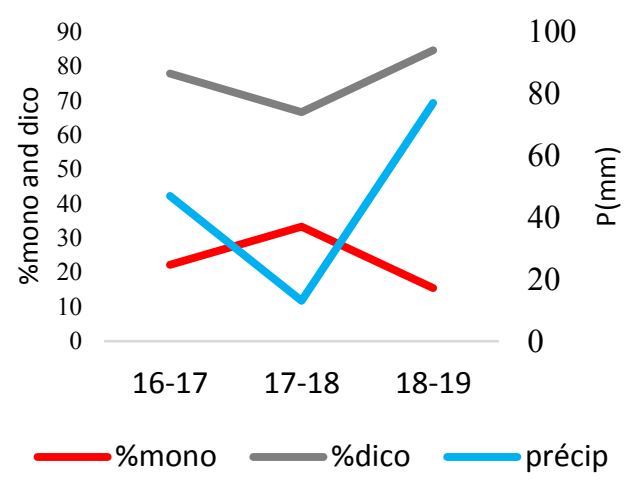

Fig. 3. Temporal evolution of the weed flora (monocots and dicots) regarding the precipitation of January

\section{Study of the diversity of the weed flora.}

The results showed a great variability in emergence from one season to another and within the same season, according to the type of weed plants (periods of appearance) and the cropping conditions (rotation and weed control). The Shannon-Weaver index (H') varied between 0.0265 bit and 1.781 bit (Table 4). Overall, the value of this index ( $\left.H^{\prime}\right)$ is low, which implies that the environment is not very diverse (the case of specialized environments where we generally note the dominance of a single species or a small number of species over all the species in the community). The high values of this index $\left(H^{\prime}\right)$ are observed before the glyphosate weeding operation, attesting to a fairly high presence of weed species on all observation stations. The highest score displayed in the first year of the study $(1.781 \mathrm{bit})$ is noted within the forage pea crop in the previous is a barley crop (Table 4). This same value is shown in the 3rd season (2018/2019), at the W/L/W treatment, attesting, an increased presence of weeds within these treatments. However, the counts carried out after the catch-up treatment reveal rather low values of the Shannon index ( $\left.\mathrm{H}^{\prime}\right)$, attesting a reduction of the weed population, under the effect of the chemical weeding operations. The most striking fact of the study is that in the third season (2018/2019), the indices $\left(\mathrm{H}^{\prime}\right)$ were high during the two counting observations and on all treatments (before and after weed control operations). This situation denotes not only the importance of the diversity of weed species; 07 species in the first count (before total weeding and seeding); and 06 species after the catch-up weeding and also the equitable repair of species at the observation stations (the treatments). This situation seems to be attributed to the non-control of weed management by the applied treatments within the no-till cropping system (Table 4).

On the other hand, Simpson's index varies between $21.11 \%$ and $100.00 \%$, which shows that in some conditions there is a strong dominance, punctuated by low values of richness (R). Conversely, the treatments that show low values of Simpson's index are related to high values of richness (R) (Table 4). In the 2018/2019 crop year, the entire plot is sown by durum wheat variety. The crop rotations $\mathrm{L} / \mathrm{T} / \mathrm{W}$ and $\mathrm{P} / \mathrm{T} / \mathrm{W}$ revealed low values of Simpson dominance index, ranging from 0.2181 to 0.6124 , respectively. At the beginning of the 3rd season (2018/2019), the observations made on the weed population and the scores given by the studied indices indicate low values of the Simpson dominance index, a high population of weed species, marked by a rather high index score ( $\left.\mathrm{H}^{\prime}\right)$. The Wheat/lentil/ wheat treatment has the values: $\mathrm{R}=8, \mathrm{H}^{\prime}=1.781$ and $\mathrm{D}=23.62 \%$ ).

For the comparison between the periods of application of the weed chemicals, the results obtained show that: For cereal crops, the catch-up weed control significantly decreases the richness, thus automatically decreases the diversity of the weed flora. However, by its nature as a nonremanent product, total weed control (glyphosate) only influences weed species that emerge early in the autumn.

Impact of crop rotations on weed development.

The response of the studied 04 rotations, under the explanatory effect of the Shannon (H') and Simpson (D) indices, (Fig. 4) was very variable according to the previous cereals and/ or legumes. Thus, the $\mathrm{W} / \mathrm{L} / \mathrm{W}$ treatment was distinguished by both a high specific diversity and a low dominance, with the presence of 08 species. Conversely, the treatment symbolized by the $\mathrm{P} / \mathrm{T} / \mathrm{W}$ rotation is characterized by a high 
dominance accompanied by a low diversity, with the dominance of 02 species, namely Polygonum aviculare and Papaver rhoeas (Fig. 4). This controversial behaviour leads the farmer adopting direct seeding to undertake rotations that can favour dominance to the detriment of diversity, allowing him to manage with more ease the control of the weed flora. It is important to note that in the no-till farming is required to manage the surface layer, which constitutes the bulk of the weed seed stock (Essahat, 2015). The use of an integrated control based on herbicide (glyphosate), supported by diversified and long rotations, leads after 3-4 years to the depletion of the superficial seed stock (El brahli \& Mrabet; 2000).

TABLE 4. Study of the weed flora using some indices during three campaigns

\begin{tabular}{|c|c|c|c|c|c|}
\hline Periods & Rotations & $\begin{array}{c}\text { Richness } \\
\mathbf{R}={ }^{0} \mathbf{D}\end{array}$ & $\begin{array}{c}\text { Shannon Entropy } \\
H^{\prime}=\ln \left({ }^{1} \mathrm{D}\right)\end{array}$ & $\begin{array}{c}\text { Shannon's } \\
\text { equitability H'/Hmax }\end{array}$ & $\begin{array}{c}\text { Simpson } \\
\text { Dominance: } \lambda\end{array}$ \\
\hline \multicolumn{6}{|c|}{ 2016/2017 agricultural Campaign } \\
\hline \multirow{4}{*}{$\begin{array}{l}\text { Before catch-up } \\
\text { weeding }\end{array}$} & $\mathrm{W}$ & 5 & 1,069 & 0,6642 & 0,5743 \\
\hline & $\mathrm{T}$ & 6 & 1,315 & 0,7339 & 0,3565 \\
\hline & $\mathrm{L}$ & 5 & 0,847 & 0,5266 & 0,3565 \\
\hline & $\mathrm{P}$ & 6 & 0,937 & 0,5229 & 0,4770 \\
\hline \multirow{4}{*}{$\begin{array}{l}\text { After catch-up } \\
\text { weeding }\end{array}$} & $\mathrm{W}$ & 2 & 0,0427 & 0,06172 & 0,9862 \\
\hline & $\mathrm{T}$ & 3 & 0,0265 & 0,00241 & 0,9933 \\
\hline & $\mathrm{L}$ & 2 & 0,0533 & 0,0769 & 0,9817 \\
\hline & $\mathrm{P}$ & 2 & 0,0235 & 0,0339 & 0,9931 \\
\hline \multicolumn{6}{|c|}{ 2017/2018 agricultural Campaign } \\
\hline \multirow{4}{*}{$\begin{array}{l}\text { Before applying } \\
\text { glyphosate }\end{array}$} & $\mathrm{W} / \mathrm{L}$ & 5 & 1,314 & 0,8167 & 0,3772 \\
\hline & $\mathrm{T} / \mathrm{P}$ & 5 & 1,781 & 1,107 & 0,2111 \\
\hline & $\mathrm{L} / \mathrm{W}$ & 3 & 0,2066 & 0,4131 & 0,8008 \\
\hline & $\mathrm{P} / \mathrm{T}$ & 5 & 1,6393 & 0,8055 & 0,3825 \\
\hline \multirow{4}{*}{$\begin{array}{l}\text { After applying } \\
\text { glyphosate }\end{array}$} & $\mathrm{W} / \mathrm{L}$ & 2 & 0,5607 & 0,8089 & 0,6800 \\
\hline & $\mathrm{T} / \mathrm{P}$ & 2 & 0,4162 & 0,6005 & 0 \\
\hline & $\mathrm{L} / \mathrm{W}$ & 1 & 0 & / & 1 \\
\hline & $\mathrm{P} / \mathrm{T}$ & 1 & 0 & l & 1 \\
\hline \multicolumn{6}{|c|}{ 2018/2019 agricultural Campaign } \\
\hline \multirow{4}{*}{$\begin{array}{l}\text { Before applying } \\
\text { glyphosate }\end{array}$} & $\mathrm{W} / \mathrm{L} / \mathrm{W}$ & 8 & 1,781 & 0,8563 & 0,2362 \\
\hline & $\mathrm{T} / \mathrm{P} / \mathrm{W}$ & 7 & 1,482 & 0,7618 & 0,3208 \\
\hline & $\mathrm{L} / \mathrm{W} / \mathrm{W}$ & 6 & 1,404 & 0,7836 & 0,3238 \\
\hline & $\mathrm{P} / \mathrm{T} / \mathrm{W}$ & 6 & 1,385 & 0,7731 & 0,3451 \\
\hline \multirow{4}{*}{$\begin{array}{l}\text { Before catch-up } \\
\text { weeding }\end{array}$} & $\mathrm{W} / \mathrm{L} / \mathrm{W}$ & 7 & 1,458 & 0,7491 & 0,2698 \\
\hline & $\mathrm{T} / \mathrm{P} / \mathrm{W}$ & 7 & 1,501 & 0,7713 & 0,2688 \\
\hline & $\mathrm{L} / \mathrm{W} / \mathrm{W}$ & 7 & 1,661 & 0,8538 & 0,2181 \\
\hline & $\mathrm{P} / \mathrm{T} / \mathrm{W}$ & 7 & 1,558 & 0,8005 & 0,6124 \\
\hline \multirow{4}{*}{$\begin{array}{l}\text { After catch-up } \\
\text { weeding }\end{array}$} & $\mathrm{W} / \mathrm{L} / \mathrm{W}$ & 6 & 1.004 & 0,5604 & 0,4300 \\
\hline & $\mathrm{T} / \mathrm{P} / \mathrm{W}$ & 6 & 1,358 & 0,7578 & 0,3909 \\
\hline & $\mathrm{L} / \mathrm{W} / \mathrm{W}$ & 6 & 1,248 & 0,6967 & 0,4165 \\
\hline & $\mathrm{P} / \mathrm{T} / \mathrm{W}$ & 6 & 1,262 & 0,7042 & 0,4079 \\
\hline
\end{tabular}

$\mathbf{W}=$ Wheat, $\mathbf{T}=$ Triticale, $\mathbf{L}=$ Lentil, $\mathbf{P}=$ Peas.

Egypt. J. Agron. 43, No. 3 (2021) 


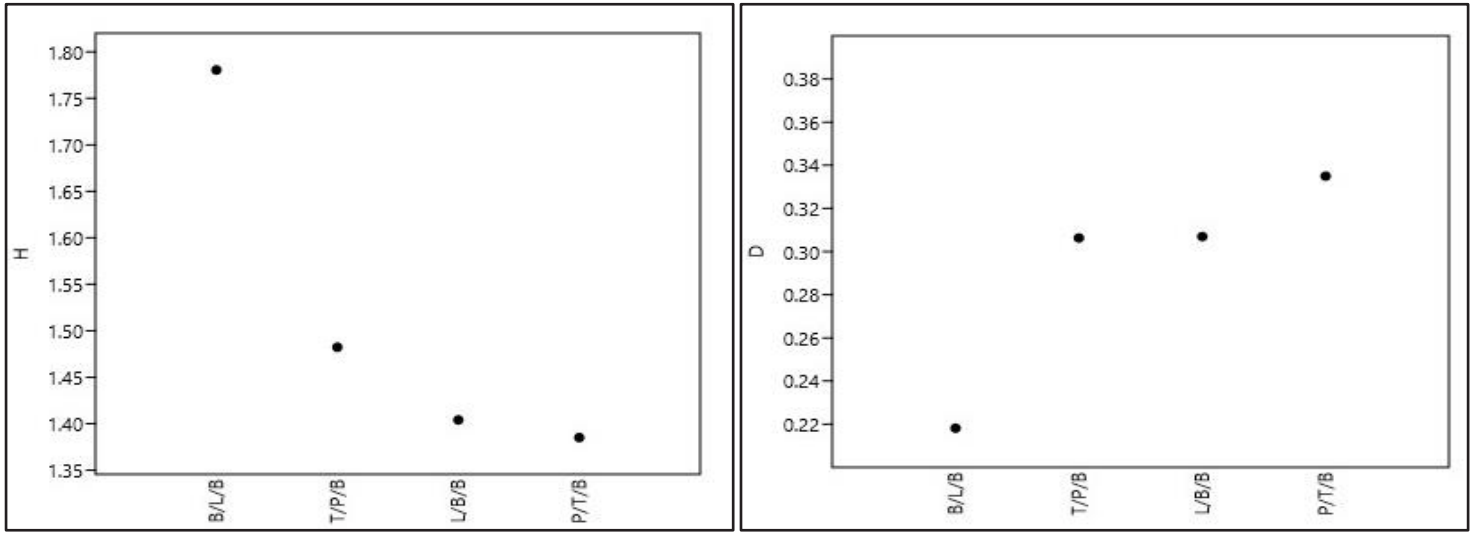

Fig. 4. variation in Shannon diversity (H') and Simpson abundance (D) (2017/2018 agricultural campaign)

A principal component analysis (PCA) was performed to make a graphical checking and therefore verify the location of the measured variables in relation to the treatments, namely the previous crop (durum wheat, triticale, lens, and forage pea) (Fig. 5). The first two axes of the PCA explain 89.80\% (2016/2017), 94.55\% (2017/2018) and $92.35 \%(2018 / 2019)$ of the total variation. Thus axis 1, explains 56.34\% (2016/2017), $64.80 \%(2017 / 2018)$ and $57.84 \%$ (2018/2019)
(Fig. 5), while the second axis contains: $33.47 \%$ (2016/2017) 29.75\% (2017/2018) and 34.51\% $(2018 / 2019)$. For the different treatments the reading of the values reported by the two axes indicates that the axis1 is positively related to the treatments whose previous is a cereal (durum wheat, triticale). On this same axis 1 , is linked negatively the treatments whose previous is a leguminous (forage pea, lens).

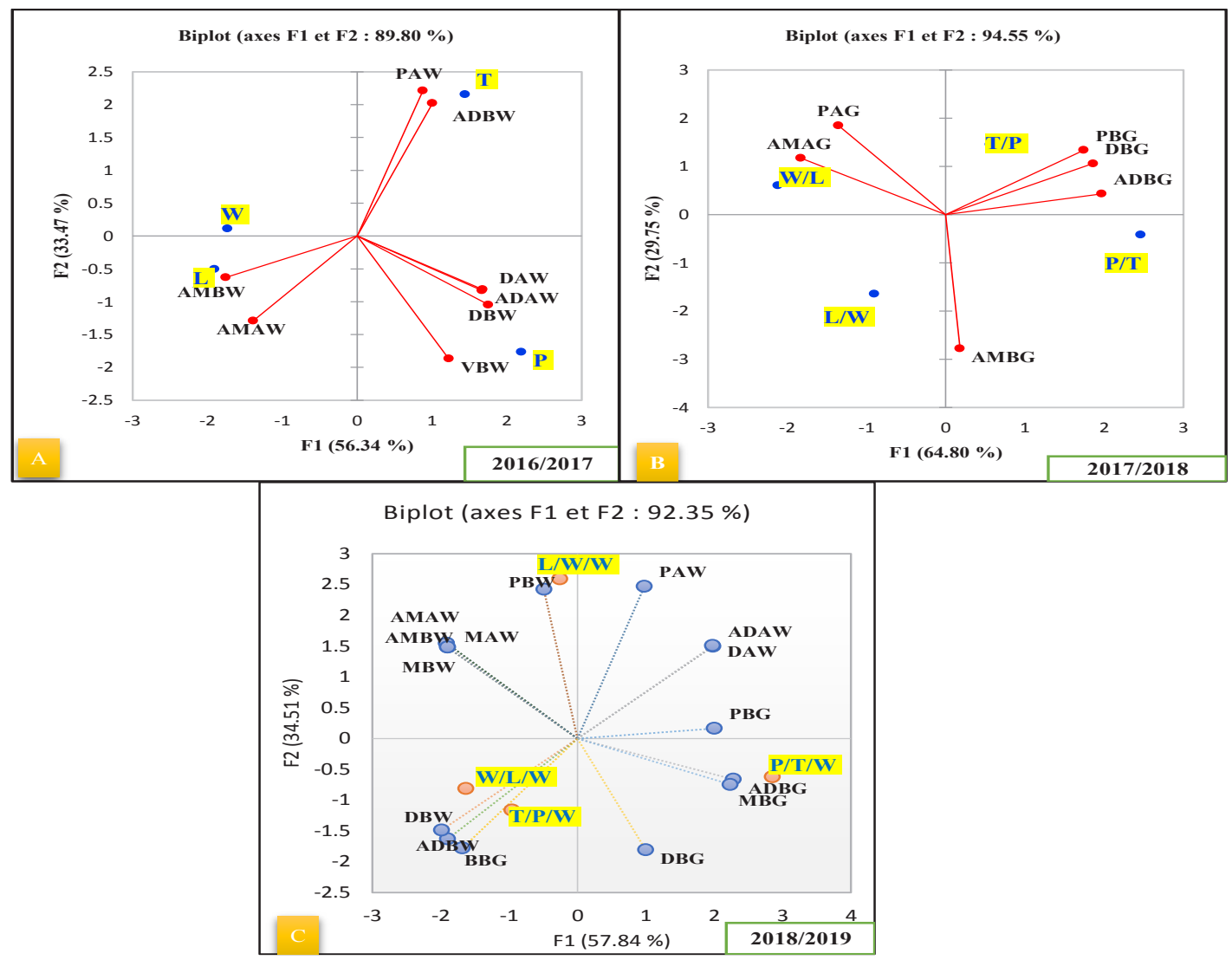

Fig. 5. Evolutionary temporal representation of the measured variables, relative to the studied treatments (rotations) on the plane formed by axes 1 and 2 of the principal component analysis 
Figure $5 \mathrm{c}$ summarizes the situation of the weed flora for the 04 studied treatments, the $\mathrm{L} / \mathrm{W} / \mathrm{W}$ treatment is located on the positive side of axis 2 and is linked to the cryptophyte plants (perennials) before the catch-up weeding (PBW) and the perennials identified after the catch-up weeding (PAW). On the opposite side of this group and on the negative side of the same axis, we observe the positioning of the $\mathrm{T} / \mathrm{P} / \mathrm{W}$ and $\mathrm{P} / \mathrm{T} / \mathrm{W}$ treatments (treatments formed by legumes) forming a solid group together with the weed species of broadleaf types before the application of catch-up weed control (DBW), broadleaf annuals before the application of catch-up weed control (ADBW) and biennial species before the application of glyphosate (BBG). However, the $\mathrm{P} / \mathrm{T} / \mathrm{W}$ treatment falls on the positive side of axis 1 and is strongly linked to the species observed before the application of total glyphosate weed control of grass (Bromus sterilis and Avena sterilis) and broadleaf therophytes. This treatment is opposed to the other two rotations constituted by legumes (forage pea and lens) namely: W/L/W and $\mathrm{T} / \mathrm{P} / \mathrm{W}$.

Overall, Figure 5c shows that the cereal-based treatments (triticale and durum wheat) were most effective in controlling perennial weed species (Cirsium arvensis and Diplotaxis assurgens), while the legume-based rotations (lentil and pea) appeared to have no effect on broadleaf weed control. This relative control of annual weed species by cereal-based rotations (Bromus sterilis and Avena sterilis), seems to be attributed to the effect of the catch-up treatment done on triticale and durum wheat during the tillering vegetative stage. The positive role played by the glyphosate weeding operation carried out after seeding should be noted for all the treatments.

\section{Conclusion}

In the present study, different traits were evaluated by estimating various effects under notill cropping systems, the proliferation of weeds is partly controlled by tillage (ploughing and shallow cultivation), combined with the use of herbicides. However, in no-till agriculture only the chemical option integrated with the adoption of rotations and competitive practices is possible. In this regard, this work was undertaken with the aim of knowing and understanding the evolution of the weed flora under no-till conditions and in parallel, testing a possible eco-friendly

Egypt. J. Agron. 43, No. 3 (2021) management effect of crop rotations on weeds. For this purpose, different rotations based on cereals and legumes were developed, namely: wheat/lentil/wheat, lentil/wheat/wheat, triticale/ forage pea/wheat and forage pea/triticale/wheat and tested during 03 crop years 2016/17, 2017/18 and $2018 / 19$. We believe that this work could be continued with longer and more diversified rotations by integrating crops that are sown in spring such as corn and spring chickpeas. In our study, the amounts of precipitation recorded in January contributed significantly to the emergence of the second wave of dicotyledon weeds. the management of the weed flora in no-till remains a major constraint and reading our results, we suggest that we should move towards long and diversifying crop rotations, by introducing crops which are sown in spring.

\section{References}

Benniou, R., Zab, K., Terraf, H., Benkherbache, N., Mebarkia, A., Hamdani, M., et al. (2016) Effect of crop rotation on the dynamics of weeds carried out by direct sowing in semi-arid environments. Case of the Ain El-Khadra M'sila region. Agriculture Review, Special Issue, 01, 230-239.

Caussanel, J.P. (1989) Pest and weed threshold in an annual crop. Specific competitive situation. Rev. Agronomy, 03, 219-240.

Chennafi, H., Aïdoudi, A., Bouzerzour, H., Saci, A. (2006) Yield response of durum wheat (Triticum durum Desf.) cultuvar waha to deficit irrigation under semi-arid growth condition. Asian Journal of Plant Sciences, 5 ,854-860.

Come D., Thevenot, C. (1982) Environmental control of embryo dormancy and germination. In: "The Physiology and Biochemistry of Seed Development, Dormancy and Germination", Khan A. A. (Ed.), pp. 271-298. Elsevier Biomedical Press, Amsterdam, New York, Oxford, 547p.

Dajet, J. (1976) "Mathematical Models in Ecology". Masson ed., Paris, 172p.

Dajoz, R. (1975) "Precise Eecology. Fundamental and Applied Ecology". Dunod Edition. Paris, 195p.

Dajoz, R. (1996) "Precise Ecology". 6 th $^{\text {th }}$ ed. Dunod. Paris, 551p. 
Dickey, E.C., Fenster, C., Laflen, J., Mickelson, R. (1983) Effects of tillage on soil erosion in a wheat fallow rotation. Transactions of the ASAE, 26, 8140820.

Dorado, J., Delmonte, J.P., Lopez-Fando, C. (1999) Weed seedbank response to crop rotation and tillage in semiarid agroecosystems. Weed Science, 47, 67-73.

Dorado, J., Lopez-Fando, C. (2006) The effect of tillage system and use of a paraplow on weed flora in a semiarid soil from central Spain. Weed Research, 46, 424-431.

El brahli, A., Mrabet, R. (2000) Chemical fallow to revive non-irrigated cereal cultivation in semi-arid Moroccan environments. In: "Breeding of National Day on Weeding of Cereals". Arido Culture Center, Settat-Morocco, 589p.

Emberger, L. (1971) "Botany and Ecology Work". Ed Masson, Paris, 520p.

Essahat, A. (2015) Direct sowing in the Sais plateau: For better integration into local cropping systems. INRA Meknes Magazine March issue, 2015.

Fortas, B., Mekhlouf, A., Hamsi, K., Boudiar, R., Laouar, A.M., Djaïdjaa, Z. (2013) Impacts of cultivation techniques on the physical behavior of the soil and the cultivation of durum wheat (Triticum durum Desf.) Under semi-arid conditions in the Sétif region. Agriculture Journal, 06, 12 - 20.

Gallandt, E.R. (2004) Soil-improving practices for ecological weed management. In: "Weed Biology and Management", pp. 267-284 Springer.

Gallandt, E.R. (2006) How can we target the weed seedbank? Weed Science, 54, 588-596.

Girard, M-C., Walter, C., Rémy, J-C., Berthelin, J., Morel J-L. (2011) "Soil and Environment". $2^{\text {nd }}$ ed Dunod. 896p.

Gobat, J., Aragon, M., Matthey, A. (2013) "Living Soil Basics of Pedologies - Soil Biology". $3^{\text {rd }}$ ed., Polytechnic, and University Presses in FrenchSpeaking Switzerland, 817p.

Haddad, L. (2017) AMMI and GGE analyzes of the genotype $\mathrm{x}$ media interaction of durum wheat (Triticum turgidum L. var. Durum) and identification of the explanatory factors of the interaction. Doctoral Thesis in Sciences. UFAS1, Algeria, p. 68.

Hamadache, A. (1995) "Weeds of Field Crops (Biology, Ecology, Means of Control". Algeria. ITGC, p. 40.

Hurlbert, S.H. (1971) The nonconcept of species diversity: A critique and alternative parameters. Ecology, 52(4), 577-586.

Jauzein, P. (1986) Staggering and periodicity of weed emergence. Bull. Soc. Bot. Fr. Lett. Bot. 2, 155-166.

Jost, L. (2006) Entropy and diversity. Oikos, 113(2), 363-375.

Khan, A.A. (1980/1981) Hormonal regulation of primary and secondary seed dormancy. Isr. J. Bot. 29, 207-221.

Le Bourgois, T. (1993) Weeds in the cotton rotation in North Cameroon (Africa). These Doc., Unv., Montpellier II, 249p.

Montegut, J. (1980) Weeds. In: "Perspective Agricole", 42, p. 31

Popay, A.L, Cox, T., Ingle, A., Kerr, R. (1995) Seasonal emergence of weeds in cultivated soil in New Zealand. Weed Res. 35, 429-436.

Ramade, F. (1994) "Elements of Ecology, Fundamental $E c o l o g y " .2^{\text {nd }}$ ed. Edi Science International. 579p.

Rahali, A., Makhlouf, M., Benkherbache, N. (2010) Influence of the technical itinerary on the type and seed stock of the weed soil: Case of the semi-arid zone of Sétif. Proceedings of the $4^{\text {th }}$ Mediterranean Meetings of Direct Sowing, 2010, Sétg, Algeria, pp.90-99.

Rasmussen, I.A. (2004) The effect of sowing date, stale seedbed, row width and mechanical weed control on weeds and yields of organic winter wheat. Weed Research, 44, 12-20.

Rouabhi, A., Laouar, A., Mekhlouf, A., Dhehibi, B. (2018) What are the factors affecting no-till adoption in the farming system of Sétif Province in Algeria? Turkish Journal of Agriculture - Food Science and Technology, 6(6), 636-641.

Ruisi, P., Frangipane, B., Amato, G., Badagliacca, G., Egypt. J. Agron. 43, No. 3 (2021) 
DI Miceli, G., Plaia, A., Giambalvo, D. (2015) Weed seedbank size and composition in a longterm tillage and crop sequence experiment. Weed Research, 55, 320-328.

Tanji, A. (2005) "Weeds of Wheat and Barley in Morocco", INRA, Rabat.
Zeghouane, O., Abdelaoui, Z., Houassine, D. (2006) What prospects for conservation agriculture in the creative zones in Algerian conditions? Mediterranean option, series A. Arrue Ugarte J.1. (Ed). $3^{\text {rd }}$ Mediterranean Meeting of Direct Sowing, pp. 183-187.

\section{دراسة تأثير الأنواع المختلفة من المحاصيل السابقة على ديناميكيات الأعشاب الضارة تحت نظام البذر المباشر في الجزائر.

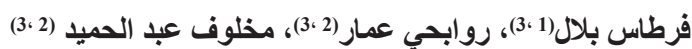

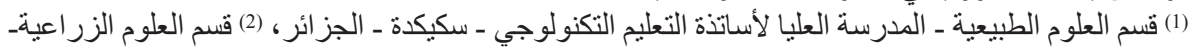 جامعة فرحات عباس - سطيف 1 ـ الجزائر، (3) مخبر تحسين وتطوير الإنتاج النباتي و الحيو اني (LIDPAP)- الجزائر.}

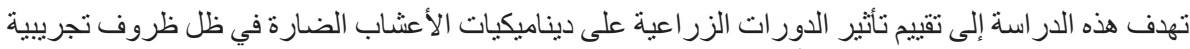

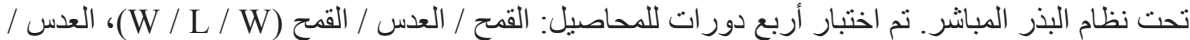

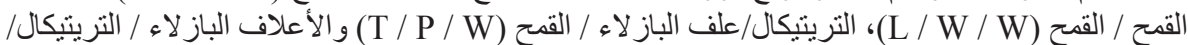

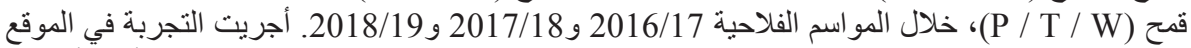

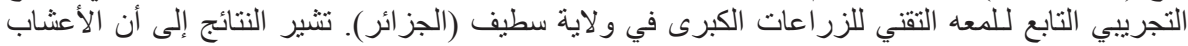

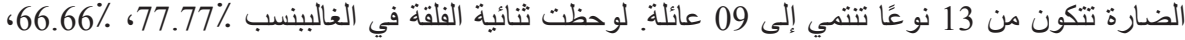
84.62\% للمو اسمالفلاحية 2016/17، 2017/18 و 2018/19 على التى التو الي. تتكون الأعشاب السنوية (أحادية الفلقة) من Bromus Sterilis و Avena Sterilis. نُظهر مؤشرات شانون وسيمبسون قيمًا مثيرة للجدل

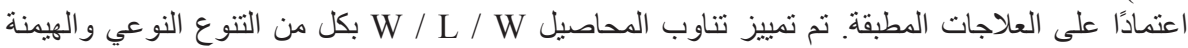

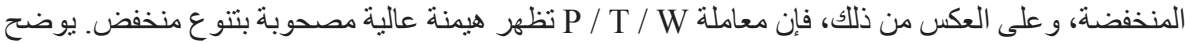

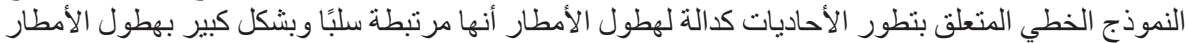
في شهر جانفي كالتالي: 